DOI: $10.17805 /$ trudy.2019.6.5

\title{
РЕАЛИЗАЦИЯ СУБЪЕКТ-СУБЪЕКТНЫХ ОТНОШЕНИЙ В ПСИХОСОЦИАЛЬНОЙ РАБОТЕ С КЛИЕНТОМ
}

\author{
В. В. Колков \\ Московский гуманитарный университет
}

\begin{abstract}
Аннотация: В статье представлена технология взаимодействия консультанта с клиентом по активизации его внутренних ресурсов и реализации субъект - субъектных отношений в психосоциальной работе. Учет социокультурного фактора по активизации студента.
\end{abstract}

Ключевые слова: социальная работа; активизация; субъект-объектные отношения; субъект-субъектные отношения

\section{THE IMPLEMENTATION OF SUBJECT-SUBJECT RELATIONS IN PSYCHOSOCIAL WORK WITH THE CLIENT}

\author{
V. V. Kolkov \\ Moscow University for the Humanities
}

\begin{abstract}
The article presents a technology of interaction between a counsellor and a client to activate their internal resources and implement subject-subject relations in psychosocial work. Consideration of the sociocultural factor of student activation.
\end{abstract}

Keywords: social work; activation; subject-object relations; subject-subject relations

Генезис социальной работы как профессиональной деятельности непосредственно связано с воплощением идей Дж. Аддамс и М. Ричмонд. Их заслуга связана как с созданием социальных служб и разработкой системы социальных услуг, так и их теоретическим осмыслением. Именно разработка теоретических основ социальной работы и введение профессиональной подготовки кадров способствовали возникновению и развитию нового профессионального вида социальной деятельности, связанной с ней прикладной науки, а в последующем и социального образования на уровне бакалавриата и магистратуры.

Основоположники социальной работы Дж. Аддамс и М. Ричмонд определили основные направления развития данного социального института: индивидуальная или клиническая социальная работа с клиентом (англ. social case work, нем. Einzelfallarbeit, фр. travail social individualise), социальная 
Научные труды Московского гуманитарного университета 2019 № 6

групповая работа (англ. social group work, нем. Gruppenarbeit, фp. service social de groupe), семейная терапия (family therapy), социальное управление и социальная политика на уровне местного самоуправления (общинная работа / развитие, англ. community organization / development, нем. Gemeinwesenarbeit, фp. développement / organisation communautaire) и в глобальном измерении - социальное изменение и развитие (social change and development).

Междисциплинарный характер теории и практики социальной работы обуславливается использованием достижений таких наук как социология, психология, политология, здравоохранение, право и экономика для взаимодействия с системами клиентов, проведения оценок и разработки мер вмешательства, решения социальных и личных проблем.

Российские исследователи выделяют следующие теоретические модели психолого-ориентированные, социолого-ориентированные (Колков, $2013,2015,2016)$ и комплексно-ориентированные.

Различные аспекты теории и практики социальной работы включены в образовательные стандарты по подготовке социальных работников, социологов и психологов. Кафедрой общей психологии и истории психологии Московского гуманитарного университета разработана программа дисциплины «Психология социальной работы».

Процесс изучения дисциплины «Психология социальной работы» направлен на формирование следующих компетенций:

ПК-4 - способностью к выявлению специфики психического функционирования человека с учетом особенностей возрастных этапов, кризисов развития и факторов риска, его принадлежности к гендерной, этнической, профессиональной и другим социальным группам;

ПК-8 - способностью к проведению стандартного прикладного исследования в определенной области психологии;

ПК-9 - способностью к реализации базовых процедур анализа проблем человека, социализации индивида, профессиональной и образовательной деятельности, функционированию людей с ограниченными возможностями, в том числе и при различных заболеваниях.

Данный перечень в некоторой степени отражает позицию Международной федерацией социальных работников по определению социальной работы, принятое на генеральной встрече в Монреале 2000 г.: «Профессия социальная работа способствует реализации социальных изменений в обществе, решению проблем человеческих взаимоотношений и укреплению свободы человека и его права на достойную жизнь. Используя теории человеческого поведения и социальных систем, социальная работа включается в процесс на этапе, когда люди взаимодействуют с окружающей средой. Принципы соблюдения прав человека и социальной справедливости явля- 
ются фундаментальными для социальной работы» (New Definition of Social Work, 2000: 4).

Для понимания сущности социальной работы по интервенции в ситуацию клиента обратимся к определению цели и задач в формулировке Ш. Рамон и Т. Шанина (Взаимосвязь ... 1997).

Основной целью социальной работы является увеличение степени социальной самостоятельности (субъектности) клиента, формирование у него навыков и умений самостоятельно строить свою жизнь и решать возникающие социальные проблемы.

В условиях перехода общества к социально ориентированной рыночной экономике перед социальной работой встают следующие задачи:

- осуществить переход от государства, декларирующего готовность решать все социальные проблемы, к самому человеку, сделать его положение более самостоятельным и независимым;

- создание условий, в которых клиенты могут в максимальной мере проявить свои возможности и получить все, что им положено по закону;

- адаптация и реадаптация (социализация и ресоциализация, абилитация и реабилитация) людей в обществе;

- создание условий, при которых человек, несмотря на физическое увечье, душевный срыв или жизненный кризис, может жить, сохраняя чувство собственного достоинства и уважение к себе со стороны окружающих;

- достижение такого результата, когда необходимость в помощи социального работника у клиента отпадает (Колков, 2006).

Таким образом, базируясь на сущности социальной работы, ее цели и задачах можно сделать заключение, что основу взаимодействия социального работника и клиента составляет технология трансформации субъект - объектных отношений в субъект - субъектные, которые позволяют клиенту самостоятельно решать возникающие проблемы и вести независимую жизнь. Сущность данной методологии можно представить следующей схемой 1.

Данная система отношений, закрепленная термином empowerment - активизация, введена в практический и научный оборот в области социаль-

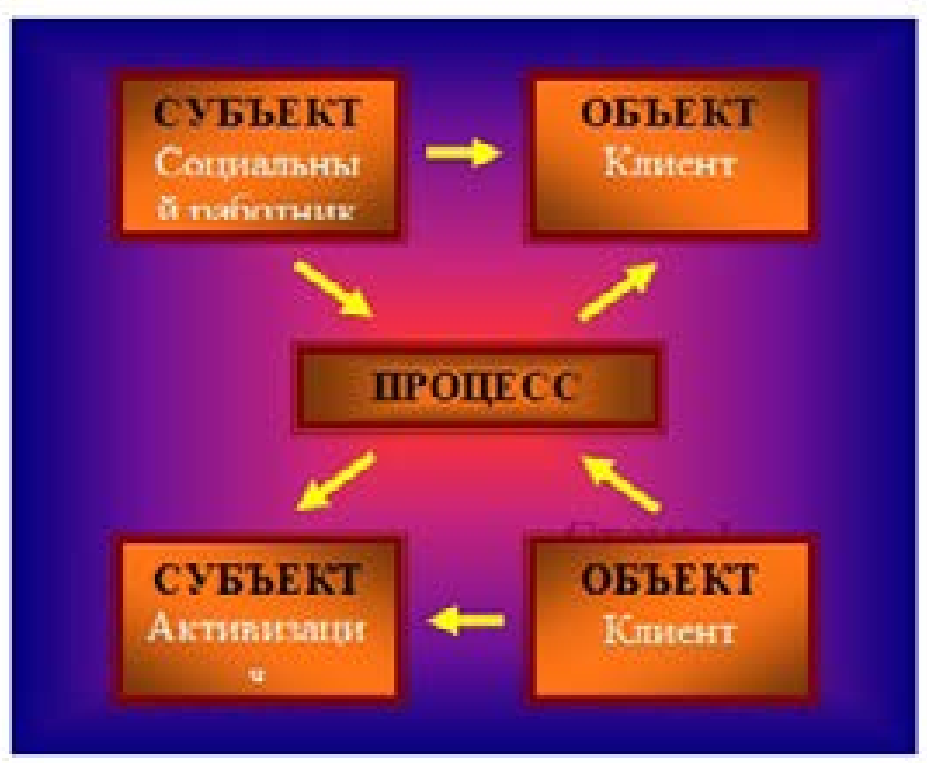

Схема 1. 
Научные труды Московского гуманитарного университета 2019 № 6

ной работы и социальной психиатрии американским психологом Дж. Раппапорт (Julian Rappaport). C 1977 г., работая в сфере общинной психологии (community psychology) и социальной психиатрии в контексте кризиса благосостояния в США, он разработал теорию активизации.

Активизация как расширение прав и возможностей относится к мерам, направленным на повышение степени автономии и самоопределения людей и сообществ, с тем чтобы они могли представлять свои интересы ответственно и самостоятельно, действуя от своего собственного авторитета. Известна цитата Раппопорт о социальной интеграции: «Наличие прав без ресурсов и доступных услуг - жестокая шутка» ${ }^{1}$.

Термин empowerment - активизация особенно популярен среди германских профессоров и социальных работников. В высшей школе социальной работы и социальной педагогики им. А. Саломон в Берлине введен сертификационный курс (Alice-Salomon-Hochschule Berlin) и магистерская программа «Empowerment Studies».

Заслуга введения в российский понятийный ряд термина активизации, как наделение клиента ресурсами, которые позволяют ему самостоятельно решать возникающие проблемы, несомненно, принадлежит кандидату психологических наук, профессору, заведующему кафедрой практической психологии Московской высшей школы социальных и экономических наук» (ОАНО «МВШСЭН») Б. Ю. Шапиро (Взаимосвязь ... , 1997; Принцип активизации ..., 1997; Управление случаем ... , 2005; Фирсов, Шапиро, 2016).

Исторически можно выделить следующие этапы восхождения от прикладной филантропии к активизации как технологии оказания социальной помощи:

1 этап - с древнейших времен - до наших дней. Социальная помощь оказывалась в виде призрения, благотворительности, филантропии, милосердия, меценатства (в современной терминологии - спонсорство);

2 этап - с конца XIX - начала XX в. - развитие социальной работы как профессиональной деятельности: медицинская модель М. Ричмонд, социальные эксперименты Дж. Аддамс. Становление основных методов социальной работы: индивидуального, группового и общинного.

3 этап - с 1960-х годов - социальная работа как вид профессиональной деятельности по защите прав человека.

4 этап - с 1980-х годов осуществление социальной работы на принципе активизации клиента.

Именно с учетом реализации методологии активизации по формированию субъект - субъектных отношений разрабатывался тренинг «Вза-

\footnotetext{
${ }^{1}$ «Having rights but no resources and no services available is a cruel joke» (Rappaport, 1981).
} 


\begin{tabular}{|c|c|c|c|c|}
\hline & I & II & III & IV \\
\hline Времи & $\begin{array}{c}\text { С Аревнейших } \\
\text { времен }\end{array}$ & G конца XIX в. & C 60-X re, XX в. & $\begin{array}{c}\text { C 80-XrT. XX } \\
\text { B. }\end{array}$ \\
\hline $\begin{array}{l}\text { Основ- } \\
\text { нан } \\
\text { ндеи }\end{array}$ & $\begin{array}{l}\text { - Милосердие } \\
\text { - Филантропия } \\
\text { - Благотворитель- } \\
\text { ность } \\
\text { - Прихрения } \\
\text { - Меценатство } \\
\text { - Спонсорство }\end{array}$ & $\begin{array}{c}\text { Социальная } \\
\text { раби как как } \\
\text { профессиональ- } \\
\text { ная } \\
\text { деятельность } \\
\text { (медицинсыая } \\
\text { модель) }\end{array}$ & $\begin{array}{c}\text { Социальная } \\
\text { рабита как } \\
\text { профессиональ- } \\
\text { ная } \\
\text { деятельность по } \\
\text { защите прав } \\
\text { человека }\end{array}$ & $\begin{array}{c}\text { Axtuenza- } \\
\text { ция }\end{array}$ \\
\hline $\begin{array}{l}\text { След- } \\
\text { ствия }\end{array}$ & $\begin{array}{c}\text { Материальная } \\
\text { зависимость }\end{array}$ & $\begin{array}{c}\text { Психологическая } \\
\text { зависимость }\end{array}$ & $\begin{array}{l}\text { Социальная } \\
\text { зависимость }\end{array}$ & $\begin{array}{c}\text { Помошь к } \\
\text { самопомо- } \\
\text { щи }\end{array}$ \\
\hline
\end{tabular}

имодействие социального работника с клиентом: проведение первичного приема» ${ }^{1}$, что нашло свое отражение в перечне ценностей и принципов социальной работы в области взаимодействия социального работника и клиента:

- признание приоритетности интересов клиента;

- соблюдение конфиденциальности отношений с клиентом;

- осуществление социальных изменений в целях удовлетворения социальных потребностей клиента;

- отделение личных чувств и потребностей социального работника от профессиональных отношений с клиентом;

- желание и умение передавать свои знания другим;

- уважение и признание индивидуальных и групповых различий;

- ориентация на развитие способностей клиента к самопомощи;

- предприятие действий, направленных на снятие фрустрации у клиента;

- ориентация на социальную справедливость и достижение экономического, физического и психологического благополучия для индивида и всех членов общества; ведения;

- ориентация на высокие стандарты личного и профессионального по-

- безоценочность;

- ответственность клиента за принятое решение;

${ }^{1}$ Шапиро, Б. Ю., Доул, М., Колков, В. В. (1997) Взаимодействие социального работника с клиентом: проведение первичного приема: Учебный видеофильм по курсу «Теория и практика социальной работы» [Электронный ресурс]. 
- недирективность;

- уважение клиента и его прав;

- приоритет защиты прав клиента;

- партнерские отношения.

При проведении тренингов для активизации самих студентов необходимо учитывать социокультурный фактор. Часто приходится сталкиваться с таким фактом, что используя термины: архетип, паттерн, персона и др., ощущаешь абстрактное восприятие понятийного ряда студентами. Обращение к социокультурной реальности позволяет использовать метод «мозгового штурма» для поиска наиболее адекватного объяснения терминов и понятий. Так, например, предлагается выявить архетипы, которые отражаются в сказках и мифах, анекдотах и культуре, в частности в художественных фильмах. Как средство достижения полноты понимания собственного «я» в психотерапии целесообразно обращение к психотерапевтической техники «активного воображения» К. Г. Юнгу, который идентифицировал мандалу как архетипический символ человеческого совершенства.

При предприятии действий, направленных на снятие фрустрации у клиента, предлагается рассмотреть факторы влияющих на появление страха, агрессии, стресса и выявить психотерапевтические возможности медитации, аутогенной тренировки и других психотехник.

\section{СПИСОК ЛИТЕРАТУРЫ}

Колков, В. В. (2006) Теория социальной работы: основные категории и понятия, факты: конспект лекций. М.: Изд-во Моск. гуманит. ун-та.

Колков, В. В. (2013) Чикагская школа социологии как основание теории и практики социальной (общинной) работы // Высшее образование для XXI века: X Международная научная конференция. Москва, 14-16 ноября 2013 г.: Доклады и материалы. Секция 2. Социология образования / отв. ред. Н. А. Селиверстова. М.: Изд-во Моск. гуманит. ун-та. С. 30-45.

Колков, В. В. (2015) Социологическое образование в структуре программы повышения квалификации: из опыта реализации социального проекта // Высшее образование для XXI века: XII Международная научная конференция. Москва, 3-5 декабря 2015 г.: Доклады и материалы. Секция 2. Социология образования / отв. ред. Н. А. Селиверстова. М.: Изд-во Моск. гуманит. ун-та. С. 25-32.

Колков, В. В. (2016) Учебная дисциплина «Теория и практика социальной работы» для социологов // Высшее образование для XXI века: XIII Международная научная конференция. Москва, 8-10 декабря 2016 г.: Доклады и материалы в 2-х частях. Секция 2. Социология образования / отв. ред. Н. А. Селиверстова. Часть 1. М.: Изд-во Моск. гуманит. ун-та. С. 50-55. 
Взаимосвязь социальной работы и социальной политики (1997) / под ред. Ш. Рамон; пер. с англ. под ред. Б.Ю. Шапиро. М.: Аспект Пресс.

Принцип активизации в социальной работе (1997) / под ред. Ф. Парслоу; пер. с англ. под ред. Б. Ю. Шапиро. М.: Аспект Пресс.

Управление случаем в социальных службах при междисциплинарном взаимодействии в решении проблем детей (2005) / автор-состав. Х. Хаубро; пер. с англ.; науч. ред. Б. Ю. Шапиро. М.: Полиграф сервис.

Фирсов, М. В., Шапиро, Б. Ю. (2016) Психология социальной работы: содержание и методы психосоциальной практики: учебное пособие для прикладного бакалавриата. М.: Юрайт.

New Definition of Social Work (2000) // IFSW NEWS. № 2. P. 4-5.

Rappaport, J. (1981) In praise of paradox. A social policy of empowerment over prevention // American Journal of Community Psychology. February, Volume 9, Issue 1, pp 1-25.

Дата поступления: 12.12.2019 г.

Колков Владимир Васильевич - кандидат исторических наук, профессор кафедры социологии Московского гуманитарного университета. Адрес: 111395, Россия, г. Москва, ул. Юности, д. 5. Тел.: +7 (499) 374-60-21. Эл. адрес: ko48@mail.ru

Kolkov Vladimir Vasilyevich, Candidate of History, Professor, Department of Sociology, Moscow University for the Humanities. Postal address: 5, Yunosti St., Moscow, Russian Federation, 111395. Tel.: +7 (499) 374-60-21. E-mail: ko48@ mail.ru

\section{Для цитирования:}

Колков В. В. Реализация субъект-субъектных отношений в психосоциальной работе с клиентом [Электронный ресурс] // Научные труды Московского гуманитарного университета. 2019. № 6. URL: http://journals.mosgu.ru/trudy/article/view/1096 (дата обращения: дд.мм.гг.). DOI: 10.17805/trudy.2019.6.5 